\title{
Maternal health training priorities for nursing and allied professions in Haiti
}

\author{
Amelia J. Brandt, ${ }^{1}$ Julio Pedroza, ${ }^{2}$ Silvia H. de Bortoli Cassiani, ${ }^{1}$ Samantha Brown, ${ }^{3}$ and Fernando A. \\ Menezes da Silva ${ }^{1}$
}

Suggested citation Brandt AJ, Pedroza J, Cassiani SHB, Brown S, Silva FAM. Maternal health training priorities for nursing and allied professions in Haiti. Rev Panam Salud Publica. 2020;44:e67. https://doi.org/10.26633/RPSP.2020.67

ABSTRACT

Objectives. This study summarizes the findings of a training needs and priority assessment completed in Haiti. Its objective is to describe the characteristics of nursing and allied professions providing first level maternal health care and identify training needs and priorities to inform planning of Human Resources for Health interventions.

Methods. A cross-sectional survey was completed between October 2016 and March 2017 by the Pan American Health Organization/World Health Organization Haiti office in collaboration with national health authorities. Participants reached consensus to submit one finalized version of the survey. Data were collected on composition, capacities, and training needs and priorities of traditional birth attendants, community health workers, registered nurses, professional midwives, and auxiliary nurses.

Results. Haiti relies heavily on community level workers including community health workers, auxiliary nurses, and traditional birth attendants. Traditional birth attendants attend the majority of Haiti's births, despite having low education levels and not being regulated by the Ministry of Public Health and Population. All professional categories prioritize preventive capacities such as timely identification of complications, while none are trained to manage postpartum hemorrhage, preeclampsia, or eclampsia. Management of obstetric emergencies is a training priority for Haiti but is not part of the scope of work of the nursing and allied health professions included in this study.

Conclusions. Community level health workers are key in providing preventive care and referral of complicated pregnancies, but lack of access to providers qualified to treat obstetric complications remains a challenge to reducing maternal mortality.

Keywords Workforce; maternal health services; maternal mortality; primary health care; capacity building; strategic planning; Haiti.

Each day in 2017, 810 women around the world died as a result of preventable pregnancy- or childbirth-related complications, and $94 \%$ of these deaths occurred in developing countries (1). In 2019, the maternal mortality ratio (MMR) of Latin America and the Caribbean was less than half of the global ratio of 211 deaths per 100000 births $(1,2)$. However, the MMR in the Latin Caribbean was much higher at 197, and Haiti's MMR was the highest in the Western Hemisphere, at 359 deaths for every 100000 births (2). The neonatal mortality rate in Haiti was similarly high at 32 deaths per 1000 live births compared to 20.4 in the Latin Caribbean (2).

Haiti's MMR declined nearly 40\% from 2006 to 2013 but not all women were affected equally due to pervasive and increasing inequities, especially between rural and urban populations (3).

\footnotetext{
Pan American Health Organization/World Health Organization, Washington DC, United States of America. $\triangle$ Amelia Brandt, brandt.amelia@gmail.com

2 Pan American Health Organization/World Health Organization, Port-au-Prince, Haiti.
} 
The leading causes of maternal mortality in Haiti in 2017 were hemorrhage, eclampsia, abortion, and sepsis, which are consistent with leading causes worldwide $(3,4)$.

Haiti is committed to universal health coverage and access as evidenced by the 25-year National Health Policy developed in 2012, one of whose main objectives is provision of women's health services (5). Unfortunately, access to maternal health services is limited and many barriers exist. As of 2017 only $42 \%$ of women in Haiti received qualified obstetric assistance at birth, and this proportion varied widely by income and location (6). Antenatal care coverage was also low at $67 \%$ compared to $88.4 \%$ in the Latin Caribbean, and $38 \%$ of women experienced an unmet need for family planning $(2,6)$. Financial and geographic barriers to accessing maternal health care are pervasive, but women also report barriers related to social status, poor perceptions of quality of care, and poor treatment by health workers (7-9).

Haiti's health system is characterized by a plethora of health providers and a highly privatized, informal, and poorly regulated market (10). Of the approximately 900 health care facilities in the country, $38 \%$ are public and only $43 \%$ offer delivery services (11). The variety of health actors makes it difficult for the Haitian government to ensure that health services are aligned with their priorities (3). Additionally, the public sector is poorly funded and provides limited coverage in rural areas (10). Haiti also faces the challenge of having extremely low human resources for health (HRH) density. Haiti has only 0.65 doctors, nurses, and midwives per 1000 people, well below the World Health Organization recommendation of 4.45 per 1000 $(12,13)$.

The Ministry of Public Health and Population (Ministère de la Santé Publique et de la Population, MSPP) in Haiti developed its first HRH strategy in 2018, which elaborates strategies to ameliorate these challenges $(12,13)$. The strategy builds on the family health team model developed after the 2010 earthquake, which focused on recruitment and training of community health workers (CHWs) who are supervised by family health teams comprised of a physician, two nurses, and four auxiliary nurses $(3,12,14)$. The HRH strategy also includes mechanisms to improve oversight and regulation of the private health sector, including international and local not-for-profit organizations $(12,13)$. Additionally, the MSPP is working to strengthen Basic Emergency Obstetric and Neonatal Care units in the country through provision of qualified staff (3). Toward this end, the MSPP and the United Nations Population Fund opened a school for professional midwives in 2013 (15).

The Pan American Health Organization/World Health Organization (PAHO/WHO) promotes increasing access to qualified health workers to achieve universal health access and universal health coverage in the Americas and plays a key role in providing technical support to Member States to improve capacity for strategic HRH planning (16). Identifying training priorities, as done in this study, is a key element of such planning (16).

In 2017, as part of the Integrated Health Systems in Latin America and the Caribbean project funded by Global Affairs Canada, $\mathrm{PAHO} / \mathrm{WHO}$ assessed maternal health training priorities for nursing and allied personnel working in primary care in Haiti. The study objective was to identify the characteristics and training priorities of HRH providing maternal health services at the primary level. These data are intended to inform training efforts for nursing and allied professions implemented by $\mathrm{PAHO} / \mathrm{WHO}$, the MSPP, and private and not-for-profit actors in the health sector.

\section{MATERIALS AND METHODS}

This study utilized cross-sectional survey methodology to collect data between October 2016 and March 2017. The $\mathrm{PAHO} / \mathrm{WHO}$ Haiti office completed the survey instrument in collaboration with high-level government personnel with a system-wide perspective on national maternal health $\mathrm{HRH}$ needs, using a consensus approach to produce one unified response to the survey instrument.

The instrument has been used in Bolivia, Colombia, Ecuador, Guatemala, Honduras, Nicaragua, and Peru and consisted of three sections: Health Care Personnel, Training Needs, and Country Resources. The survey gathered information about five categories of professionals providing maternal health care at the primary level: traditional birth attendants (TBAs), CHWs, registered nurses (RNs), auxiliary nurses, and professional midwives. The development and content of the first section of the instrument has previously been described in the literature (17).

In the Training Needs section, the authors collected data on existing maternal health training, relevant cultural factors, and available training resources. The first set of questions in this portion were open-ended and arranged in a table, in which the number of courses, frequency, content, duration, and evaluation of continuing education were captured in cells corresponding to each health worker category. The survey used multiple-choice questions to collect information regarding entities responsible for continuing education, the role of continuing education in professional licensing, available training resources, and specific training needs by service area (prevention, routine care, treatment, and other). An open-ended question asked for priority geographic regions in need of maternal health training. The authors used a single open-ended question to obtain a description of relevant cultural factors that could impact maternal health practice or training.

In the Country Resources section, the authors collected information about national resources available for implementation of training programs among maternal health care personnel in areas of supplies, technology, and human resources. The authors used a table to capture availability and functionality of the following resources: cable Internet, wireless Internet, laboratories or spaces for practical training, computers, cellular phones, and other (e.g., television, radio, fax). In this table, the authors also collected the names of departments and establishments in which each resource was available, in addition to a rating of the functionality of each resource on a four-point scale (poor, fair, good, excellent). The authors used an open-ended question to identify geographic locations lacking facilities with the resources mentioned. The authors also collected information on e-learning resources through a multiple-choice question used to determine whether virtual training courses existed for each category of health worker, and if so, which entity offered them.

Upon receiving the completed survey instrument, the Health Systems and Services/Human Resources team based at $\mathrm{PAHO} / \mathrm{WHO}$ Headquarters in Washington, D.C. reviewed 
the information and worked with the Haiti office to resolve any inconsistencies and finalize the data. The team then analyzed and synthesized the data in draft form and shared the draft with the Haiti office for review. The Health Systems and Services/ Human Resources team then made necessary revisions identified by the Haiti office and shared the final version with the Haiti office for approval. The document was finalized with approval from the Haiti office and Health Systems and Services/Human Resources team in Washington in October 2017.

The Health Systems and Services/Human Resources team submitted this study proposal to the PAHO Ethics Review Committee, which determined it exempt from review as it was not research with human subjects.

\section{RESULTS}

\section{Profiles and scope of health personnel}

This study collected information regarding TBAs, CHWs, auxiliary nurses, RNs, and professional midwives. Table 1 presents a summary of the characteristics of each category of health worker. CHWs are the largest professional category, followed by RNs, although data were not provided for TBAs or auxiliary nurses. Professional midwives and TBAs are the only categories of worker that attend births, and TBAs attend $51 \%-75 \%$ of births in the country. Transportation, funds, and accessibility are barriers to access to RNs and professional midwives, as well as to referral of complicated births to health centers by auxiliary nurses, CHWs, and TBAs. Despite these barriers, auxiliary nurses, CHWs, and TBAs refer $76 \%-100 \%$ of complicated births to health centers, and TBAs generally have referral agreements with health centers.

Professional licenses are required for RNs and professional midwives, but do not require completion of an exam or other knowledge-testing activity or renewal. However, the completion of an exam is required at the end of nursing school and midwifery school. TBAs have the lowest level of education, followed by auxiliary nurses and CHWs, although CHWs are required to complete a four-month training program.
Additionally, TBAs generally speak Creole only, and less than $25 \%$ are estimated to be literate. Professional midwives and RNs are required to complete $4-5$ and 2-3 years of post-secondary education, respectively.

TBAs are the only category of health workers not regulated by or paid by the MSPP, although mothers pay TBAs for their services and they are recognized and preferred by women in the communities where they work. The average age of auxiliary nurses, CHWs, professional midwives, and RNs varies but is considerably younger than that of TBAs, who are on average older than 61. Professional midwives are the youngest group with an average age of 15 to 25 .

Each category of health worker is present in each of Haiti's 10 departments; however, TBAs are concentrated in rural areas, while RNs are more prominent in the Ouest Department.

Table 2 presents the necessary capacities to properly practice for each of the five categories of health worker roles discussed above. The capacities necessary for TBAs, CHWs, and auxiliary nurses are similar, although TBAs are the only category to attend uncomplicated deliveries. CHWs and auxiliary nurses provide services that TBAs do not, such as preventive care against infections and family planning services. Auxiliary nurses must also have the capacity to provide neonatal and prenatal care.

Capacities needed by RNs and professional midwives overlap with those of TBAs, CHWs, and auxiliary nurses in some areas, but there are no capacities that are required for all five groups. RNs and professional midwives must be competent in many more areas than other categories of health workers, as illustrated in Table 2.

\section{Continuing education}

The MSPP offers continuing education with distinct training modules to all health personnel providing maternal health services, apart from TBAs. The continuing education provided for auxiliary nurses and CHWs is limited, with a duration of less than one week. Although continuing education is offered for RNs and professional midwives, these courses are not required

TABLE 1. Human resources for health characteristics, Haiti, 2017

\begin{tabular}{|c|c|c|c|c|c|}
\hline & Auxiliary nurse & Community health worker & Professional midwife & Registered nurse & Traditional birth attendant \\
\hline Number ${ }^{a}$ & $\ldots$ & $3838-4000$ & 74 & 3018 & $\cdots$ \\
\hline Percentage of births attended a & $0 \%$ & $0 \%$ & $26 \%-50 \%$ & $\cdots$ & $51 \%-75 \%$ \\
\hline $\begin{array}{l}\text { Barriers to access to health } \\
\text { worker }\end{array}$ & NA & NA & $\begin{array}{l}\text { Transportation, funds, } \\
\text { accessibility }\end{array}$ & $\begin{array}{l}\text { Transportation, funds, } \\
\text { accessibility }\end{array}$ & NA \\
\hline $\begin{array}{l}\text { Barriers to referral of complicated } \\
\text { births to health centers }\end{array}$ & $\begin{array}{l}\text { Transportation, funds, } \\
\text { accessibility }\end{array}$ & $\begin{array}{l}\text { Transportation, funds, } \\
\text { accessibility }\end{array}$ & NA & NA & Transportation \\
\hline $\begin{array}{l}\text { Percentage of complicated births } \\
\text { referred to health centers }\end{array}$ & $76 \%-100 \%$ & $76 \%-100 \%$ & NA & NA & $76 \%-100 \%$ \\
\hline License required & No & No & Yes & Yes & No \\
\hline Educational requirements & Secondary school & $\begin{array}{l}\text { Secondary school and } \\
\text { 4-month training program }\end{array}$ & $\begin{array}{l}4-5 \text { years post secondary } \\
\text { school }\end{array}$ & $\begin{array}{l}\text { 2-3 years post } \\
\text { secondary school }\end{array}$ & Primary school \\
\hline Government regulated & Yes & Yes & Yes & Yes & No \\
\hline $\begin{array}{l}\text { Paid through formal health } \\
\text { system }\end{array}$ & Yes & Yes & Yes & Yes & No \\
\hline Average age (years) & $26-40$ & $18-35$ & $15-25$ & $26-40$ & $>61$ \\
\hline
\end{tabular}

a Estimate; ${ }^{b}$ Each TBA attends approximately 10 births per month; ... No data provided; NA, Not applicable

Source: Prepared by the authors from the survey results. 
TABLE 2. Capacities necessary for practice by type of health worker, Haiti, 2017

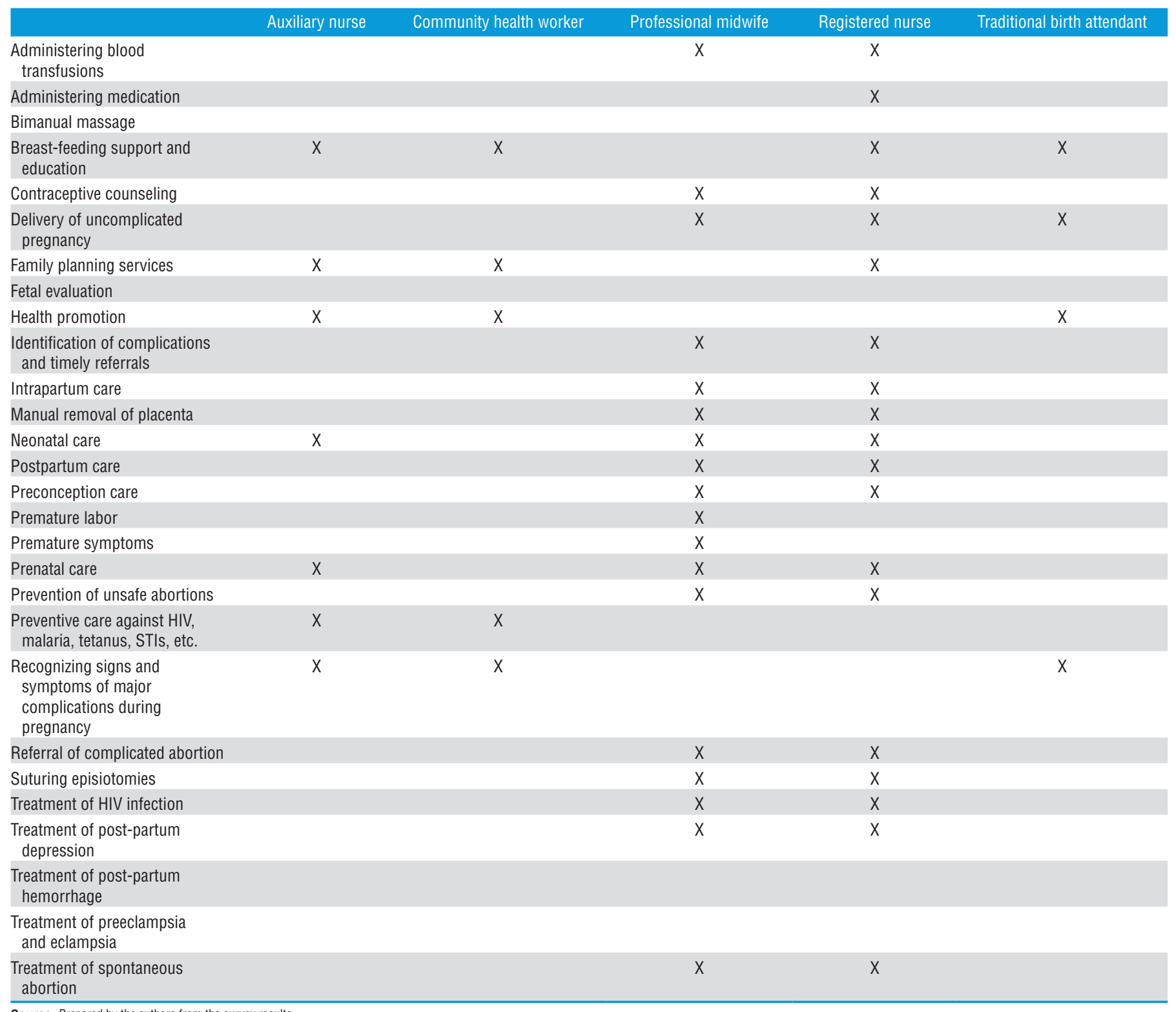

Source: Prepared by the authors from the survey results.

for maintenance of professional licenses. Online courses are not available for any health professional.

The government of Haiti has several key resources for providing training, although quality varies. Cable and wireless Internet of fair quality can be found in urban areas in each department but access in rural areas is limited, especially for wireless Internet. Laboratories and spaces of fair quality to evaluate health workers' capacities in maternal health are also available throughout the country. Haiti has good quality computers and cellular telephones throughout the country, as well as other resources such as televisions, radios, and fax machines.

\section{Needs and priorities}

Training priorities by health worker are presented in Table 3, with " $1^{\text {st" }}$ representing the highest priority. While the highest training priority is unique for TBAs, $\mathrm{CHWs}$, and auxiliary nurses, each focuses on preventive services. The second priority for TBAs, CHWs, and auxiliary nurses is recognizing signs and symptoms of major complications during pregnancy.

RNs and professional midwives share the same first and third training priorities: identification of complications and timely referrals, and treatment of HIV infection, respectively. The second priority for RNs is prenatal care, while for professional midwives it is prevention of unsafe abortion.

$\mathrm{HRH}$ training priorities classified by service area are presented in Table 4 . Some training needs are consistent with those identified in Table 3, such as family planning and contraception and early detection of complications. Emergency obstetric care is included as a training priority, although it is not included as a necessary capacity for practice for any category of health worker (see Table 2). Additional priorities to those identified 
TABLE 3. Training priorities by category of health worker, Haiti, 2017

\begin{tabular}{|c|c|c|c|c|c|}
\hline & Auxiliary nurse & Community health worker & Professional midwife & Registered nurse & Traditional birth attendant \\
\hline $\begin{array}{l}\text { Preventive care against HIV, } \\
\text { malaria, tetanus, STIs, etc. }\end{array}$ & $1^{\text {st }}$ & & & & \\
\hline Health promotion & & $1^{\text {st }}$ & & & \\
\hline Prenatal care & & & & $2^{\text {nd }}$ & \\
\hline $\begin{array}{l}\text { Delivery of uncomplicated } \\
\text { pregnancy }\end{array}$ & & & & & $3^{\text {rd }}$ \\
\hline Family planning services & $3^{\text {rd }}$ & $3^{\text {rd }}$ & & & \\
\hline Prevention of unsafe abortions & & & $2^{\text {nd }}$ & & \\
\hline $\begin{array}{l}\text { Identification of complications } \\
\text { and timely referrals }\end{array}$ & & & $1^{\text {st }}$ & $1^{\text {st }}$ & \\
\hline
\end{tabular}

Source: Prepared by the authors from the survey results.

TABLE 4. Training needs by service area, Haiti, 2017

\begin{tabular}{lll}
\multicolumn{1}{c}{ Prevention } & \multicolumn{1}{c}{ Routine care } & \multicolumn{1}{c}{ Treatment } \\
$\begin{array}{ll}\text { Preconception care and early detection of complications } \\
\text { (especially eclampsia) }\end{array}$ & Patient psychological support & Emergency obstetric care \\
Physiology and pathophysiology & Evaluation and care of neonates & Cardio-pulmonary resuscitation \\
Family planning / contraception & Fetal evaluation & Teamwork and communication \\
& & Leadership \\
& & Research \\
\hline
\end{tabular}

Source: Prepared by the authors from the survey results.

in Table 3 included human rights, leadership, and professional ethics.

\section{DISCUSSION}

Overall density of nursing and allied professions to provide maternal health care at the primary level in Haiti is low, although information was not available for the number of auxiliary nurses and TBAs. The lack of information about TBAs is especially problematic, given that they attend the majority of births in the country. The available data seem to indicate that numbers of RNs and professional midwives are limited and concentrated in the Ouest Department, pointing to a reliance on community level workers (CHWs, auxiliary nurses, and TBAs) in rural areas. Needs assessments in Colombia, Honduras, and Nicaragua were similarly limited by missing health workforce data and also indicated a reliance on community level health workers (17). However, the recent opening of a midwifery school in Haiti in 2013 and emphasis on using midwives to staff Basic Emergency Obstetric and Neonatal Care facilities are promising developments that may provide increased access to more highly trained $\operatorname{HRH}(3,15)$.

Although TBAs attend births and are preferred by some women, their work is not regulated, and they do not receive training. TBAs are generally active in rural areas, which have poorer health outcomes and a lower concentration of health professionals. It may be possible to integrate TBAs into the formal health system, although the low literacy level and advanced age of this group are barriers. Other countries in the Region, such as Ecuador, have integrated TBAs into the formal health system with promising results (18).

It is concerning that among the categories of health workers included in this study, births are attended by TBAs, who have the lowest level of education and training, and professional midwives, who have the highest level of education and training. It is likely that the health outcomes for women whose births are attended by TBAs will vary significantly from those attended by professional midwives. However, with only 76 professional midwives in Haiti, it is difficult the compare these outcomes currently. As a country characterized by considerable health inequity, it will be important to continually examine this dynamic $(3,6)$.

While CHWs and auxiliary nurses do not attend births, they play an important supportive role that complements the work of more highly trained HRH. Community-focused approaches to maternal health are essential to providing holistic and appropriate reproductive and maternal health services, and the contribution of CHWs to improving maternal health has been 
well documented $(19,20)$. Haiti's new HRH strategy emphasizes the inclusion of CHWs into the formal system and is an important step to leveraging this group to improve maternal health.

The scopes of work for TBAs, CHWs, and auxiliary nurses are limited and reflect the lower level of education necessary for these categories of health worker compared to RNs and professional midwives, whose role is much more extensive. The scopes of work for RNs and professional midwives are complementary, with some competencies needed for RNs but not midwives, and vice versa. For example, RNs should be able to provide family planning services and administer medication, while midwives need to be capable of providing care in the case of a premature birth. Professional midwives and RNs are not restricted from providing services such as health promotion, breast-feeding support, health education, but these are not their primary focus, as is the case for community level health workers (TBAs, CHWs, and auxiliary nurses).

It is important to note fetal monitoring, management of hemorrhage, and management of preeclampsia and eclampsia are not included in the scopes of work for any of the five categories of health worker described in this study. This is concerning, as postpartum hemorrhage and eclampsia are the leading causes of maternal mortality in the country (3). While it may be inferred that these activities would fall under the scope of work of physicians, physician density is extremely low and could therefore lead to very limited access to these services, especially in rural areas.

Basic continuing education is currently in place in Haiti, which could be expanded upon and strengthened to improve maternal health service quality. It is promising that human rights and professional ethics are identified as training priorities, as these are likely to have a direct impact on improving patient experiences. Low-quality services or disrespectful care may actually worsen women's health and well-being compared to no care, and poor quality of care and poor treatment by health workers have been identified as barriers to access to care in Haiti $(21,22)$. Quality of maternal health services must be improved at all levels to continue positive trends in maternal health in Haiti $(21,23)$. HRH interventions focusing on management, education, and policy have been shown to improve HRH capacity and maternal health outcomes (24), especially when targeting primary health care services $(25,26)$.

Additionally, basic infrastructure to provide training is present in each of Haiti's 10 departments but should be expanded to rural areas to allow for training of HRH serving the most vulnerable women.

Haiti's training priorities emphasize the importance of preventive services for TBAs, CHWs, and auxiliary nurses, while also illustrating the unique roles and scopes of practice for each. The identification of recognition of signs and symptoms of complications during pregnancy as a training priority for TBAs, $\mathrm{CHWs}$, and auxiliary nurses is indicative of the importance of early identification and referral to reduce maternal mortality (27). This is also reflected in the prioritization of training on recognizing complications and providing timely referrals for both RNs and professional midwives.

The emphasis placed on family planning services for both $\mathrm{CHWs}$ and auxiliary nurses is appropriate given the low rate of contraceptive prevalence, high unmet need for family planning, and the influence that high parity and unwanted pregnancies have on maternal mortality $(27,28)$. Family planning is also identified as a priority for preventive care.

Obstetric emergencies are a training priority in the overall treatment service area, but this is not reflected in training priorities for RNs or professional midwives, nor is it included in their scope of work. This highlights the importance of management of obstetric emergencies, while also raising important questions of how these services are to be provided given the limited number of health professionals qualified to do so. Respondents also indicated that several of what are sometimes called "soft" skills are also training priorities, such as teamwork, communication, and leadership. Although these skills are often overlooked in training programs, poor communication has been shown to increase maternal mortality, and improving communication within care teams can improve maternal health (29).

This study provides information that can be used by health actors in Haiti to improve the alignment of their training activities with the priorities of the MSPP and HRH needs. However, this study has several limitations. The data in this study present a broad overview and may not capture important geographical variations in training priorities and may also fail to reflect changes in priorities since the development of the HRH strategy in 2018. Further research exploring the needs and priorities of the maternal health workforce since the 2018 strategy was developed is recommended. It may also be prudent to examine training needs and priorities in each department as geographical variation is possible.

\section{Conclusions}

Achieving universal access to health and universal health coverage is a $\mathrm{PAHO} / \mathrm{WHO}$ key priority and is of foremost importance to reducing maternal mortality and morbidity in Haiti and throughout the Region. Through the Strategy on Human Resources for Universal Access to Health and Universal Health Coverage, PAHO/WHO provides a roadmap for how to leverage and maximize application of human resources toward this goal.

As in many countries in the Region of the Americas, limited $\mathrm{HRH}$ in Haiti is a challenge to reducing maternal mortality. The adoption of a community-focused model of health delivery is a significant step to increase access to maternal health services using available $\mathrm{HRH}$ and is supported by the findings of this study. However, increased access to $\mathrm{HRH}$ trained to address obstetric emergencies such as postpartum hemorrhage should remain a priority to save women's lives in Haiti.

Author contributions. FAMS and SHBC conceived the original idea of the assessment. JP collected the data. AJB, SB, and JP analyzed the data. AJB, SB, JP, and SHBC interpreted the results. AJB and SB wrote the original draft of the paper. SHBC, FAMS, and JP reviewed the paper. All authors reviewed and approved the final version.

\section{Conflicts of interest. None declared.}

Disclaimer. Authors hold sole responsibility for the views expressed in the manuscript, which may not necessarily reflect the opinion or policy of the RPSP/PAJPH and/or PAHO. 


\section{REFERENCES}

1. Trends in maternal mortality 2000 to 2017: estimates by WHO, UNICEF, UNFPA, World Bank Group and the United Nations Population Division [Internet]. Geneva: World Health Organization; 2019. 104 p. Available from: https://www.unfpa.org/ featured-publication/trends-maternal-mortality-2000-2017

2. Pan American Health Organization. Core indicators 2019: health trends in the Americas [Internet]. Washington DC: PAHO; 2019. Available from: https://iris.paho.org/bitstream/handle/10665.2/ 51542/9789275121290_eng.pdf

3. Pan American Health Organization/World Health Organization. Health in the Americas, Country Report: Haiti. Washington DC: $\mathrm{PAHO} / \mathrm{WHO} ; 2017$.

4. Say L, Chou D, Gemmill A, Tunçalp Ö, Moller A-B, Daniels J, et al. Global causes of maternal death: a WHO systematic analysis. Lancet Glob Health [Internet]. 2014;2(6):e323-33. Available from: https://www.sciencedirect.com/science/article/pii/S2214109X $1470227 X$

5. Ministère de la Santé Publique et la Population (Haiti). Politique nationale de santé [Internet]. Port-au-Prince: MSPP; 2012. Available from: https://extranet.who.int/countryplanningcycles/sites/ default/files/country_docs/Haiti/haiti_politique_national_de_ sante_2012.pdf

6. Institut Haitien de l'Enfance (Haiti); DHS Program ICF. Enquête mortalité, morbidité et utilisation des services (EMMUS-VI), 20162017 [Internet]. Petion-Ville, Haiti and Rockville MD: IHE and ICF; 2018. Available from: https://www.dhsprogram.com/pubs/pdf/ FR326/FR326.pdf

7. Babalola SO. Factors associated with use of maternal health services in Haiti: a multilevel analysis. Rev Panam Salud Publica. 2014;36(1):1-9.

8. Perkins J, Capello C, Vilgrain C, Groth L, Billoir H, Santarelli C. Determinants of low maternal and newborn health service utilization in Haiti: a community-based cross-sectional study. J Womens Health Issues Care. 2017;2017:1-8.

9. Herrera J, Lamaute-Brisson N, Milbin D, Roubaud F, Saint-Macary C, Torelli C, et al. L'évolution des conditions de vie en Haïti entre 2007 et 2012: la réplique sociale du séisme. Paris, Port-au-Prince: IHSI, DIAL; 2014.

10. Durham J, Michael M, Hill PS, Paviignani E. Haïti and the health marketplace: The role of the private, informal market in filling the gaps left by the state. BMC Health Serv Res [Internet]. 2015;15:424. Available from: https://doi.org/10.1186/s12913-015-1088-5

11. Institut Haitien de $l^{\prime}$ Enfance (Haiti); ICF International. Évaluation de la prestation des services de soins de santé, Haiti, 2013 [Internet]. Rockville MD: IDE/ICF International; 2013. Available from: https://mspp.gouv.ht/site/downloads/EPSSS.pdf

12. United States Agency for International Development, Health Finance and Governance. HFG Haiti final report. Washington DC: USAID; 2018

13. Scheffler R, Cometto G, Tulenko K, Bruckner T, Liu J, Keuffel EL, et al. Health workforce requirements for universal health coverage and the Sustainable Development Goals - background paper N.1 to the WHO Global Strategy on Human Resources for Health: Workforce 2030. Human Resources for Health Observer Series 17 [Internet]. Geneva: World Health Organization; 2016. Available from: https://apps.who.int/iris/bitstream/handle/10665/250330/ 9789241511407-eng.pdf

14. Ministère de la Santé Publique, Direction des Ressources Humaines. Plan national de développement des ressources humaines pour la santé 2030. Port-au-Prince: Ministère de la Santé Publique, Haiti; 2018. p. 61.

15. United Nations Population Fund [Internet]. New York: UNFPA; 2013 Nov 6. A New Midwifery School Brings Hope to Haitian Mothers.
Available from: https://www.unfpa.org/news/new-midwiferyschool-brings-hope-haitian-mothers

16. Pan American Organization/World Health Organization. Resolution CD52.R13: Human resources for health: Increasing access to qualified health workers in primary health care-based health systems. Presented at 52nd Directing Council; 30 Sep-4 Oct [Internet]. Washington DC: PAHO; 2013. Available from: https://iris.paho. org/handle/10665.2/4441

17. Brandt AJ, Brown S, Cassiani SHDB, Silva FAM da. Maternal health training priorities for nursing and allied health workers in Colombia, Honduras, and Nicaragua. Rev Panam Salud Publica. 2019;43:e7.

18. Llamas A, Mayhew S. "Five hundred years of medicine gone to waste"? Negotiating the implementation of an intercultural health policy in the Ecuadorian Andes. BMC Public Health. 2018;18(1):686.

19. Early JO, Burke-Winkelmann S, Joshi A. On the front lines of prevention: Promotores de Salud and their role in improving primary care for Latina women, families, and communities. Glob J Health Educ Promot. 2016;17(2):58-86.

20. Perry HB, Zulliger R, Rogers MM. Community health workers in low-, middle-, and high-income countries: an overview of their history, recent evolution, and current effectiveness. Annu Rev Public Health. 2014;35:399-421.

21. Graham WJ, Varghese B. Quality, quality, quality: gaps in the continuum of care. Lancet. 2012;379(9811):e5-6.

22. Perkins J, Capello C, Vilgrain C, Groth L, Billoir H, Santarelli C. Determinants of low maternal and newborn health service utilization in Haiti: a community-based cross-sectional study. J Womens Health Issues Care. 2017;6(1):1-8.

23. World Health Organization. The world health report 2005: make every mother and child count. Geneva: WHO; 2005.

24. Lassi ZS, Musavi NB, Maliqi B, Mansoor N, de Francisco A, Toure $\mathrm{K}$, et al. Systematic review on human resources for health interventions to improve maternal health outcomes: Evidence from low- and middle-income countries. Hum Resour Health [Internet]. 2016;14:10. Available from: https:/ /doi.org/10.1186/s12960-016-0106-y

25. Bhutta ZA, Ali S, Cousens S, Ali TM, Haider BA, Rizvi A, et al. Alma-Ata: Rebirth and Revision 6 Interventions to address maternal, newborn, and child survival: what difference can integrated primary health care strategies make? Lancet. 2008;372(9642):972-89.

26. Jennings MC, Pradhan S, Schleiff M, Sacks E, Freeman PA, Gupta $\mathrm{S}$, et al. Comprehensive review of the evidence regarding the effectiveness of community-based primary health care in improving maternal, neonatal and child health: 2. maternal health findings. J Glob Health. 2017;7(1):010902.

27. World Health Organization. Maternal mortality: Fact sheet No. 348. Geneva: WHO; 2015.

28. Bauserman M, Lokangaka A, Thorsten V, Tshefu A, Goudar SS, Esamai F, et al. Risk factors for maternal death and trends in maternal mortality in low- and middle-income countries: a prospective longitudinal cohort analysis. Reprod Health [Internet]. 2015;12(suppl 2):S5. Available from: https:/ / doi.org/10.1186/1742-4755-12-S2-S5

29. Brennan RA, Keohane CA. How communication among members of the health care team affects maternal morbidity and mortality. J Obstet Gynecol Neonatal Nurs. 2016;45(6):878-84.

Manuscript submitted on 4 December 2019. Revised version accepted for publication on 19 March 2020. 


\section{Prioridades de capacitación en salud materna para la enfermería y profesiones auxiliares en Haití}

RESUMEN Objetivos. En este estudio se resumen los resultados de la evaluación de necesidades y prioridades de capacitación realizada en Haití. Su objetivo es describir las características de la enfermería y las profesiones auxiliares que prestan el primer nivel de atención de salud materna, y establecer las necesidades y las prioridades de capacitación a fin de diseñar la planificación de recursos humanos para las intervenciones de la salud. Métodos. La Representación de la Organización Panamericana de la Salud/Organización Mundial de la Salud en Haití realizó una encuesta transversal entre octubre del 2016 y marzo del 2017, en colaboración con las autoridades nacionales de salud. Los participantes consensuaron presentar una versión ultimada de la encuesta. Se recopilaron datos sobre la composición, las capacidades y las necesidades y las prioridades de capacitación de las parteras tradicionales, los agentes comunitarios de salud, las enfermeras tituladas, las parteras profesionales y las enfermeras auxiliares.

Resultados. Haití depende en gran medida de trabajadores comunitarios, entre los que se incluyen los agentes comunitarios de salud, las enfermeras auxiliares y las parteras tradicionales. Las parteras tradicionales atienden la mayoría de los nacimientos en Haití, a pesar de disponer de un nivel bajo de formación y no estar reguladas por el Ministerio de Salud Pública y Población. Todas las categorías profesionales priorizan las capacidades preventivas, como la detección temprana de las complicaciones, si bien no están capacitadas para controlar la hemorragia posparto, la preeclampsia o la eclampsia. El tratamiento de las urgencias obstétricas es una prioridad de la capacitación en Haití, pero no forma parte del ámbito de trabajo de la enfermería y las profesiones auxiliares incluidas en este estudio.

Conclusiones. Los trabajadores de salud a nivel comunitario son clave para la prestación de atención preventiva y derivación de los embarazos complicados, pero la falta de acceso a prestadores cualificados para tratar las complicaciones obstétricas es todavía un obstáculo para reducir la mortalidad materna.

Palabras clave

Recursos humanos; servicios de salud maternal; mortalidad materna; atención primaria de salud; creación de capacidad; planificación estratégica; Haití.

\section{Prioridades na formação de enfermeiros e profissionais da saúde auxiliares na área da saúde materna no Haiti}

RESUMO Objetivos. Este estudo resume os resultados de uma avaliação sobre as necessidades prioritárias na formação de profissionais da saúde no Haiti. Seu objetivo é descrever as características do trabalho de enfermeiros e profissionais da saúde auxiliares na prestação de atenção primária para a saúde materna e identificar as necessidades prioritárias de formação, a fim de fundamentar o planejamento de intervenções voltadas aos recursos humanos para a saúde.

Métodos. O Escritório da Organização Pan-Americana da Saúde/Organização Mundial da Saúde no Haiti, em colaboração com as autoridades nacionais de saúde, realizou um inquérito transversal entre outubro de 2016 e março de 2017. Os participantes chegaram a um consenso, apresentando uma versão finalizada do inquérito. Foram coletados dados sobre a composição, as capacidades e as necessidades prioritárias de formação de parteiras tradicionais, agentes comunitários de saúde, enfermeiros, parteiras profissionais e auxiliares de enfermagem.

Resultados. O Haiti é muito dependente de trabalhadores de nível comunitário, como agentes comunitários de saúde, auxiliares de enfermagem e parteiras tradicionais. As parteiras tradicionais atendem a maioria dos partos no Haiti, apesar de terem um baixo nível de escolaridade e não serem regulamentadas pelo Ministério de Saúde Pública e População. Todas as categorias profissionais priorizam as capacidades preventivas, como a rápida identificação de complicações, e nenhuma recebe formação para lidar com hemorragia pós-parto, pré-eclâmpsia ou eclâmpsia. A formação para o tratamento de emergências obstétricas é uma prioridade no Haiti, mas não faz parte do escopo de trabalho dos enfermeiros e profissionais da saúde auxiliares incluídos neste estudo.

Conclusões. Os profissionais da saúde de nível comunitário são fundamentais na prestação de cuidados preventivos e no encaminhamento de gestações complicadas, mas a falta de acesso a profissionais qualificados para tratar complicações obstétricas ainda é um obstáculo nos esforços para reduzir a mortalidade materna.

Palavras-chave Recursos humanos; serviços de saúde maternal; mortalidade materna; atenção primária à saúde; fortalecimento institucional; planejamento estratégico; Haiti. 